\title{
The Newly Murky World of Searches Incident to Lawful Arrest: Why the Gant Restrictions Should Apply to All Searches Incident to Arrest ${ }^{*}$
}

\section{INTRODUCTION}

Jesus Perdoma stepped out of a large black SUV at the Omaha Greyhound bus terminal in the early morning of November 17, 2008, carrying a single bag. ${ }^{1}$ Without saying goodbye to the person nice enough to drop him off so early, Perdoma nervously started walking into the terminal. ${ }^{2}$ He was not alone, though; his behavior had attracted the attention of Alan Eberle, a plain-clothes Nebraska State Patrol investigator on duty outside the terminal. ${ }^{3}$ Eberle trailed Perdoma at a distance from the SUV to the ticket counter before sidling up behind him to hear Perdoma's conversation. ${ }^{4}$ Eberle noticed Perdoma's governmentissued identification card in his wallet as Perdoma pulled out cash to buy his one-way ticket under the name Jesus Cruz. ${ }^{5}$ Perdoma could not stop shaking. ${ }^{6}$ The pair left the ticket counter, and Eberle asked Perdoma if he would answer a few questions. ${ }^{7}$ Perdoma began lying: he did not have any identification and a cab, not an SUV, dropped him off. ${ }^{8}$ Perdoma still could not stop shaking. ${ }^{9}$ Having talked to Perdoma for a short time, Eberle started to smell marijuana. ${ }^{10}$ He asked to see Perdoma's wallet. ${ }^{11}$ Perdoma reached to his back pocket, pulled out his

Sean Foley. J.D. 2012 University of Kansas School of Law. I would like to thank Professor Thomas Stacy, Steve Hengeli, Joe Schremmer, and the Kansas Law Review staff for their help, hard work, and feedback throughout this process. A huge thanks, as well, to my wife, Erin, for her friendship, advice, help, and support.

1. United States v. Perdoma, 621 F.3d 745, 747 (8th Cir. 2010), cert. denied, 131 S. Ct. 2446 (2011).

2. Id.

3. Id.

4. Id.

5. Id.

6. Id.

7. Id.

8. Id. at $747-48$.

9. Id. at 748 .

10. Id.

11. Id. 
wallet, and paused before handing it to Eberle. ${ }^{12}$ Then he stuck his wallet back in his pants and took off. ${ }^{13}$

After a short chase, Eberle and another trooper tackled and arrested Perdoma. ${ }^{14}$ He was handcuffed, restrained by the two officers, and moved to a different part of the terminal. ${ }^{15}$ At this point-with Perdoma arrested but with the bag away from him and under control of a police officer-should Eberle be worried about searching Perdoma's bag without a warrant? The answer to that question prior to the recent and transformative United States Supreme Court decision Arizona v. Gant ${ }^{16}$ was unquestionably no. From 1969 to 2009, no court would have told Eberle that he could not search Perdoma's bag incident to Perdoma's lawful arrest. For these thirty years the Supreme Court emphasized creating clear rules to govern when and where police officers may search after an arrest to help them operate consistently in stressful and dangerous situations. After all, policing is a terribly dangerous job, and the moments after an arrest are stressful and unpredictable; courts recognize that society must provide police officers a certain degree of leeway.

Thus, for the last thirty years, the United States Supreme Court sought to produce bright-line rules granting police officers wide latitude in conducting a search after arresting a person. Indeed, one United States magistrate judge aptly summarized the Court's case law from this period by stating that "a search incident to arrest is absolute."17 But this sentiment is no longer accurate. In 2009, the Supreme Court in Gant reversed one major bright-line rule it had employed for decades in favor of a more fact-intensive and difficult-to-employ test. ${ }^{18}$ Gant's narrow holding was that an officer no longer has absolute authority to search a vehicle after arresting one of its occupants. ${ }^{19}$ But, Gant's broad dicta seemingly undermine numerous other bright-line rules giving police broad authority to search after an arrest outside the vehicle context. This narrow holding coupled with broad dicta has left Fourth Amendment jurisprudence regarding searches incident to arrest "in a confused and

\footnotetext{
12. Id.

13. Id.

14. Id.

15. Id.

16. 556 U.S. 332 (2009).

17. Perdoma, $621 \mathrm{~F} .3 \mathrm{~d}$ at 748 (internal quotation marks omitted).

18. Gant, 556 U.S. at 355-56 (Alito, J., dissenting).

19. Id. at 351 (majority opinion).
} 
unstable state." $^{20}$ In this murky haze, a circuit split between two United States Circuit Courts of Appeals has developed over whether Gant's restrictions apply to all searches incident to arrest, or merely to arrests in the vehicle context.

This Comment asks and answers two questions. First, do Gant's restrictions limiting when an officer may search a vehicle apply outside the vehicle context to limit all searches incident to an arrest? This Comment answers that question in the affirmative; Gant replants the exception in the Court's historical precedents that do not lend themselves to bright-line rules. Second, if the restrictions do apply, what is the proper test to apply them? This Comment argues that the United States Court of Appeals for the Third Circuit's "access factor test" should be widely adopted. Part II below summarizes the search incident to arrest exception's case law, including Gant. Part III outlines two courts of appeals decisions and one federal district court decision about whether Gant's restrictions apply to all searches incident to arrest. Part IV argues in support of the Third Circuit's position that Gant's restrictions should apply to all searches incident to an arrest and that other federal courts should adopt its access factor test.

\section{THE SEARCH INCIDENT TO ARREST EXCEPTION: BACKGROUND}

The Fourth Amendment to the United States Constitution provides:

The right of the people to be secure in their persons, houses, papers, and effects, against unreasonable searches and seizures, shall not be violated, and no Warrants shall issue, but upon probable cause, supported by Oath or affirmation, and particularly describing the place to be searched, and the persons or things to be seized. ${ }^{21}$

It is designed to "prohibit [] warrantless searches."22 This oftrepeated maxim often precedes a litany of exceptions to the general rule. ${ }^{23}$ One of these exceptions is the search incident to a lawful arrest. ${ }^{24}$

20. Id. at 363 (Alito, J., dissenting).

21. U.S. CONST. amend. IV.

22. See, e.g., United States v. Curtis, 635 F.3d 704, 711 (5th Cir. 2011).

23. E.g., Angad Singh, Comment, Stepping Out of the Vehicle: The Potential of Arizona v. Gant to End Automatic Searches Incident to Arrest Beyond the Vehicular Context, 59 AM. U. L. REV. 1759, 1763 (2010) ("Nevertheless, the general rule that a warrantless search is unconstitutional has been significantly weakened by a plethora of exceptions that have greatly expanded the power of police to conduct warrantless searches.”).

24. Id. (citing Thornton v. United States, 541 U.S. 615, 627 (2004)). For purposes of this Comment, the search incident to arrest exception will also be referred to as "the exception." 
This exception allows a police officer after arresting a person to search that person, the area around that person, and that person's bags. ${ }^{25}$

\section{A. Chimel v. California: The Modern Origins of the Search Incident to Arrest Exception}

The Supreme Court recognized the exception before fully delineating its modern parameters in the landmark case of Chimel v. California. ${ }^{26}$ In Chimel, police officers served an arrest warrant on Chimel at his home for the burglary of a coin shop, but lacked a search warrant to search his house. ${ }^{27}$ Nonetheless, the officers searched his entire house after Chimel refused consent. ${ }^{28}$ The search was detailed and took nearly an hour while the police removed evidence of the crime. ${ }^{29}$

The Court upheld the warrantless search and outlined the modern search incident to arrest exception:

When an arrest is made, it is reasonable for the arresting officer to search the person arrested in order to remove any weapons that the latter might seek to use in order to resist arrest or affect his escape. Otherwise, the officer's safety might well be endangered, and the arrest itself frustrated. In addition, it is entirely reasonable for the arresting officer to search for and seize any evidence on the arrestee's person in order to prevent its concealment or destruction. And the area into which an arrestee might reach in order to grab a weapon or evidentiary items must, of course, be governed by a like rule. A gun on a table or in a drawer in front of one who is arrested can be as dangerous to the arresting officer as one concealed in the clothing of the person arrested. $^{30}$

Thus, the exception allows law enforcement to search "the arrestee's person and the area 'within his immediate control'-construing that phrase to mean the area from within which he might gain possession of a

25. Id. at 1766 (citing United States v. Robinson, 414 U.S. 218, 235 (1973)).

26. 395 U.S. 752, 759-60 (1969) (noting an earlier decision which "has come to stand for the proposition, inter alia, that a warrantless search 'incident to a lawful arrest' may generally extend to the area that is considered to be in the 'possession' or under the 'control' of the person arrested (citing United States v. Rabinowitz, 339 U.S. 56 (1950))); see also Singh, supra note 23, at 1763-64 (noting the Court spoke about the "right" to search incident to arrest in Weeks v. United States and outlined an expansive search power in United States v. Rabinowitz).

27. Chimel, 395 U.S. at 753.

28. Id. at 753-54; see also Chelsea Oxton, Note, The Search Incident to Arrest Exception Plays Catch Up: Why Police May No Longer Search Cell Phones Incident to Arrest Without a Warrant, 43 CREIGHTON L. REV. 1157, 1164-66 (2010).

29. Chimel, 395 U.S. at 754.

30. Id. at 762-63. 
weapon or destructible evidence.”31 The exception's two main purposes-officer safety and preventing destruction of evidence-still define the boundaries of the search incident to arrest exception. ${ }^{32}$ For the exception to apply, the search must occur contemporaneously with the arrest because the more time between the arrest and the search, the less likely the search can be justified as necessary to preserve officer safety or preserve evidence. $^{33}$

\section{B. United States v. Robinson: A Clear Line for Searches of a Person and Containers Incident to Arrest}

After Chimel, it took the Supreme Court four years to address how the search incident to arrest exception applies to searching bags or containers that were on or had been connected to the recent arrestee's person. $^{34}$ In United States $v$. Robinson, Robinson was arrested for a driving license violation. ${ }^{35}$ After Robinson was arrested (and it is not clear if he was handcuffed or not) the officer began patting him down. ${ }^{36}$ The officer felt something in his shirt's breast pocket but could not tell exactly what it was. ${ }^{37}$ The officer reached into Robinson's shirt pocket and pulled out a container, which turned out to be a "crumpled up cigarette package." ${ }^{38}$ The officer then opened the cigarette package and discovered heroin. ${ }^{39}$

The Supreme Court held that this search was a valid search incident to arrest. $^{40}$ The Court reasserted Chimel's policy justifications of allowing searches of the arrestee and the area within her immediate control after an arrest to protect both evidence and officers. ${ }^{41}$ The ability to search the person incident to an arrest, the Court held, is a bright-line rule: such a search is per se reasonable. ${ }^{42}$ The existence of an arrest

\footnotetext{
31. Id. at 763 .

32. Arizona v. Gant, 556 U.S. 332, 338 (2009); see also Singh, supra note 23, at 1765 ("These twin rationales, officer safety and preservation of evidence, underpin the authority to search within the arrestee's reaching area.”).

33. Chimel, 395 U.S. at 764.

34. See Oxton, supra note 28, at 1166.

35. 414 U.S. 218, 220 (1973).

36. Id. at 223 .

37. Id.

38. Id. (internal quotation marks omitted).

39. Id.

40. Id. at 224 .

41. Id. at 226.

42. Id. at 234-35 ("This is an adequate basis for treating all custodial arrests alike for purposes of search justification.”).
} 
justifies the ability to inspect containers on the arrestee's person. ${ }^{43}$ When those containers turn up evidence of a crime-even if not of the crime for which the arrestee is arrested - the officer may seize that evidence. ${ }^{44}$

Importantly, the Court in Robinson overruled a circuit court holding that validity of a search incident to arrest after Chimel depends on a caseby-case analysis. The Court stated:

The authority to search the person incident to a lawful custodial arrest, while based upon the need to disarm and to discover evidence, does not depend on what a court may later decide was the probability in a particular arrest situation that weapons or evidence would in fact be found upon the person of the suspect. ${ }^{45}$

Also, the Court hinted at its desire to set forth bright-line rules and "rejected a suggestion that 'there must be litigated in each case the issue of whether or not there was present one of the reasons supporting the authority' to conduct such a search., 46

Justices Marshall, Brennan, and Douglas dissented in Robinson, arguing against the need to establish bright-line rules to govern this exception. ${ }^{47}$ A case-by-case analysis in which officers must show that the search was needed to either protect them or preserve evidence is preferable. ${ }^{48}$ This would not be the last time that these Justices would caution against bright-line rules. ${ }^{49}$

\section{New York v. Belton: A Bright-Line Rule for Vehicle Searches Incident to Arrest}

After Robinson set forth a bright-line rule allowing officers to search an arrestee's person after every lawful custodial arrest, New York $v$. Belton extended that rule to searches of a vehicle after arresting an occupant of that vehicle. ${ }^{50}$ In Belton, a police officer stopped a speeding car, smelled marijuana, and instructed the occupants out of the car. ${ }^{51}$ After arresting the occupants for possession of marijuana in plain view

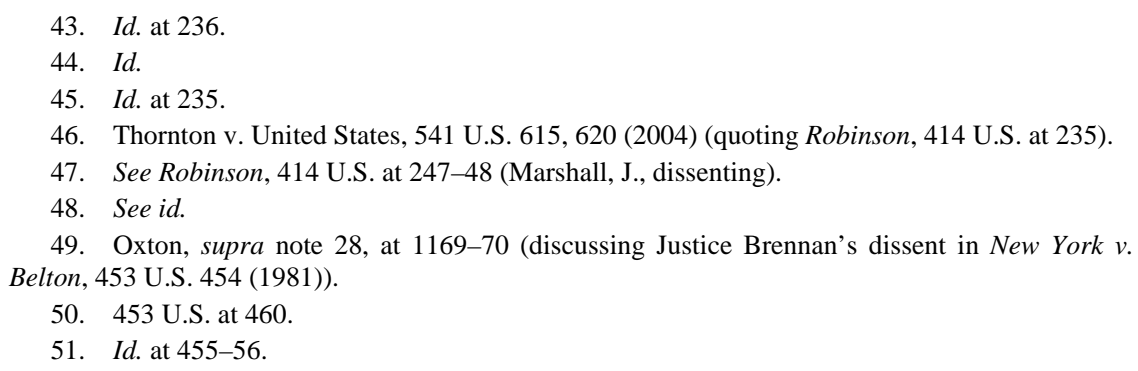


and Mirandizing them, the lone officer returned to the car and searched the entire passenger compartment. ${ }^{52}$ In the backseat of the car, the officer found a jacket. ${ }^{53}$ The officer unzipped the jacket's pocket and found cocaine. ${ }^{54}$

The Court upheld the search as a valid search incident to arrest. ${ }^{55}$ Because "courts ha[d] found no workable definition of 'the area within the immediate control of the arrestee,"” the Court decided to set forth another bright-line rule. ${ }^{56}$ Just as Robinson granted police the ability to search containers on the person, Belton gave police the ability to search not only the passenger compartments of the car, but also any containers when they lawfully arrest an occupant. ${ }^{57}$ The Belton majority emphasized the need for "familiar standards" to guide police:

When a person cannot know how a court will apply a settled principle to a recurring factual situation, that person cannot know the scope of his constitutional protection, nor can a policeman know the scope of his authority. While the Chimel case established that a search incident to an arrest may not stray beyond the area within the immediate control of the arrestee, courts have found no workable definition of "the area within the immediate control of the arrestee" when that area arguably includes the interior of an automobile and the arrestee is its recent occupant. Our reading of the cases suggests the generalization that articles inside the relatively narrow compass of the passenger compartment of an automobile are in fact generally, even if not inevitably, within "the area into which an arrestee might reach in order to grab a weapon or evidentiary ite[m]." In order to establish the workable rule this category of cases requires, we read Chimel's definition of the limits of the area that may be searched in light of that generalization. Accordingly, we hold that when a policeman has made a lawful custodial arrest of the occupant of an automobile, he may, as a contemporaneous incident of that arrest, search the passenger compartment of that automobile. ${ }^{58}$

And indeed, Belton did become a bright-line rule; for the next thirty years, until Gant, when an officer lawfully arrested a passenger of an automobile, she was able to contemporaneously search "the passenger

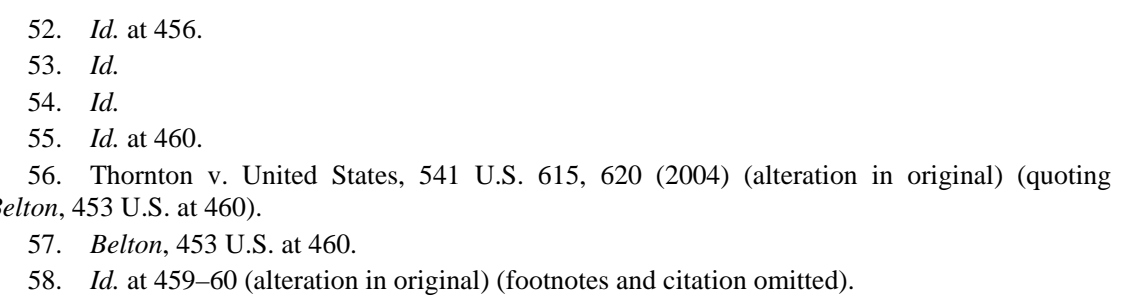


compartment of that automobile' and any containers therein” every time. $^{59}$

As he did in Robinson, Justice Brennan dissented in Belton. The majority shortcut its analysis, he argued, by concluding that the entire passenger compartment is per se within the immediate control of the arrestee. $^{60}$ This legal fiction should not displace fact-intensive tests to limit the exception. ${ }^{61}$ Justice Brennan warned that the desire for brightline rules will come back to haunt the Court. ${ }^{62}$ It seems likely that day has come.

\section{Thornton v. United States: Reasserting Belton’s Bright-Line Rule}

The Court addressed the exception thirteen years after Belton in Thornton $v$. United States. ${ }^{63}$ In Thornton, police officers grew suspicious of a driver, Thornton, after he veered into a parking lot as they pulled alongside. $^{64}$ Noticing Thornton's tags were expired, the officers followed him into the parking lot and asked him questions after he had left his car and was outside his vehicle. ${ }^{65}$ The officers grew concerned for their safety, so they asked Thornton if they could pat him down. ${ }^{66} \mathrm{He}$ consented, and the pat-down search revealed a bulge in his coat that he admitted was drugs. ${ }^{67}$ After Thornton was arrested and put in the patrol car, the officers searched his car and found a gun. ${ }^{68}$ He was ultimately convicted of possession of a firearm by a felon. ${ }^{69}$

Thornton appealed his conviction of being a felon in possession by arguing that "Belton was limited to situations where the officer initiated contact with an arrestee while he was still an occupant of the car."70 Because Thornton had left his car before encountering the police, he contended, the exception did not apply. ${ }^{71}$ The Court rejected Thornton's

\footnotetext{
59. United States v. Perdoma, 621 F.3d 745, 755 (8th Cir. 2010) (Bye, J. dissenting) (quoting Belton, 556 U.S. at 460), cert. denied, 131 S. Ct. 2446 (2011).

60. Belton, 556 U.S. at 466 (Brennan, J., dissenting).

61. See Oxton, supra note 28, at 1169-70.

62. Id. at 1170 .

63. 541 U.S. 615 (2004); see also Oxton, supra note 28, at 1170.

64. Thornton, 541 U.S. at 617-18.

65. Id. at 618 .

66. Id.

67. Id.

68. Id.

69. Id.

70. Id. at 619 (emphasis added)

71. Id.
} 
argument and maintained Belton's bright-line rule governing car searches incident to an arrest:

To be sure, not all contraband in the passenger compartment is likely to be readily accessible to a "recent occupant." It is unlikely in this case that petitioner could have reached under the driver's seat for his gun once he was outside of his automobile. But the firearm and the passenger compartment in general were no more inaccessible than were the contraband and the passenger compartment in Belton. The need for a clear rule, readily understood by police officers and not depending on differing estimates of what items were or were not within reach of an arrestee at any particular moment, justifies the sort of generalization which Belton enunciated. Once an officer determines that there is probable cause to make an arrest, it is reasonable to allow officers to ensure their safety and to preserve evidence by searching the entire passenger compartment. ${ }^{72}$

The Court made a policy judgment that the need for a clear rule justifies less scrutiny of officer actions that implicate the Fourth Amendment.

\section{E. Arizona v. Gant: The Game Changer for the Court's Bright-Line Rules}

In 2009, the Supreme Court changed everything. Arizona v. Gant repudiated Belton's bright-line rule permitting officers to search the entire passenger compartment and any container therein after any occupant's arrest. ${ }^{73}$ In Gant, police were tipped-off to the location of a drug house. ${ }^{74}$ The officers approached the house, knocked, and Rodney Gant answered. ${ }^{75}$ After the officers left because the house's owner, who was the intended target, was not home, a background check revealed an outstanding warrant for Gant, the man that answered the door, for driving on a suspended license. ${ }^{76}$ Returning later that night, the officers were watching the house when they saw Gant drive up toward the house's driveway. ${ }^{77}$ The officers approached Gant and arrested him for driving on a suspended license as he parked at the end of the driveway. ${ }^{78}$ After handcuffing and placing Gant in the patrol car, the police officers

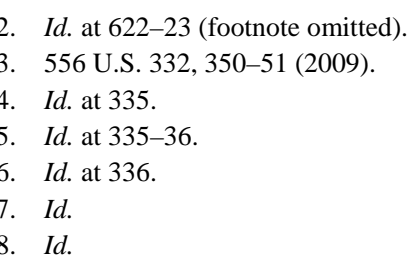


searched his car consistent with Belton and Thornton's absolute rule. ${ }^{79}$ One officer found a gun in the car and another found cocaine inside the pocket of Gant's jacket. ${ }^{80}$

Gant moved to suppress, arguing that "Belton did not authorize the search of his vehicle because he posed no threat to the officers after he was handcuffed in the patrol car and because he was arrested for a traffic offense for which no evidence could be found in his vehicle." ${ }^{81}$ The trial court rejected Gant's arguments and upheld the search. ${ }^{82}$ The Arizona Supreme Court reversed. ${ }^{83}$ The court distinguished Belton on the grounds that Belton concerns searches contemporaneous to arrest and not those undertaken once an arrestee is secured, as Gant was once placed in the patrol car. ${ }^{84}$ The Arizona Supreme Court held that when the scene is secure

the justifications underlying Chimel no longer exist because the scene is secure and the arrestee is handcuffed, secured in the back of a patrol car, and under the supervision of an officer... [therefore]... a warrantless search of the arrestee's car cannot be justified as necessary to protect the officers at the scene or prevent the destruction of evidence. $^{85}$

The dissenting justices of the Arizona Supreme Court would have done like all other courts have for the last thirty years and "upheld the search of Gant's car" because "the validity of a Belton search . . . clearly does not depend on the presence of the Chimel rationales in a particular case." ${ }^{86}$ But the justices did note that Belton's bright-line rule had been often criticized and "probably merit[ed] reconsideration." 87 The Supreme Court followed their invitation and granted certiorari to reconsider whether Belton's bright-line rule, which had become divorced from Chimel's original policy justifications, was preferable to a more nuanced test for when police officers may search vehicles incident to a lawful arrest of a recent occupant. ${ }^{88}$

\footnotetext{
79. Id.

80. Id.

81. Id.

82. Id. at 337.

83. Id. at 337-38.

84. Id. at 337.

85. Id. at 337-38 (quoting State v. Gant, 163 P.3d 640, 644 (Ariz. 2007)).

86. Id. at 338 (alteration in original) (quoting Gant, 162 P.3d at 649 (Bales, J., dissenting)) (internal quotation marks omitted).

87. Gant, 162 P.3d at 649 (Bales, J., dissenting).

88. See Gant, 556 U.S. at 342 (discussing the circuit split following Belton).
} 
Justice Stevens began the Court's analysis where it always does: by stating that warrantless searches generally violate the Fourth Amendment, subject to only a few "established and well-delineated" exceptions. $^{89}$ Then, the Court reiterated that the search incident to arrest exception is still governed by the original Chimel justifications of accounting for officer safety and evidence preservation. ${ }^{90}$ Chimel's strict limitations "continue[] to define the boundaries of the exception" because those limits "ensure[] that the scope of a search incident to arrest is commensurate with its purposes of protecting arresting officers and safeguarding any evidence of the offense of arrest that an arrestee might conceal or destroy."91

Next, the Court reviewed its holding in Belton. The Court stated Belton was simply recognition of Chimel in the vehicle context. ${ }^{92}$ But, it did note that courts had read Belton broadly as "allow[ing] a vehicle search incident to the arrest of a recent occupant even if there is no possibility the arrestee could gain access to the vehicle at the time of the search." 93 This broad reading allowing searches when the arrestee could not access the area, the Court held, is unconstitutional because it "untether[s] the rule from the justifications underlying the Chimel exception.",94

Finally, the Court unequivocally replanted the exception in the original Chimel justifications. ${ }^{95}$ "[T]he Chimel rationale authorizes police to search a vehicle incident to a recent occupant's arrest only when the arrestee is unsecured and within reaching distance of the passenger compartment at the time of the search." 96 So, applying Chimel to the facts in Gant, the search was unjustified. ${ }^{97}$ "Neither the possibility of access nor the likelihood of discovering offense-related evidence authorized the search in this case."98 Unlike in Belton, where it is possible that the need to protect officer safety still would have justified

\footnotetext{
89. Id. at 338 (citing Katz v. United States, 389 U.S. 347, 357 (1967)).

90. Id. at 339

91. Id.

92. See id. at 343.

93. Id. at 341 ("This reading may be attributable to Justice Brennan's dissent in Belton, in which he characterized the Court's holding as resting on the 'fiction . . . that the interior of a car is always within the immediate control of an arrestee who has recently been in the car.'” (alteration in original) (quoting New York v. Belton, 453 U.S. 454, 466 (1981))).

94. Id. at 343.

95. Id.

96. Id. (emphasis added).

97. Id. at 344 .

98. Id.
} 
the search because the officer was drastically outnumbered and the arrestees were unsecured, ${ }^{99}$ in Gant, all three arrestees were secured and placed in patrol cars before the search took place. ${ }^{100}$ Therefore, Gant was not within reaching distance of the car. ${ }^{101}$ Also, Gant was arrested for driving on a suspended license, which means that there could be no evidence of the crime in the car. ${ }^{102}$ Whereas in Belton, the arrestees were arrested for drug crimes and it would have been reasonable to conclude that related evidence was in the car. ${ }^{103}$ "Because police could not reasonably have believed either that Gant could have accessed his car at the time of the search or that evidence of the offense for which he was arrested might have been found therein, the search in this case was unreasonable."104

Gant explicitly rejected Belton's broad bright-line rule and, once again, tethers the search incident to arrest exception to its Chimel moorings. ${ }^{105}$ But, because this was a vehicle search incident to arrest, the Court's holding addresses the proper scope of vehicle searches incident to arrest, not all searches incident to arrest. ${ }^{106}$ This relatively normal event - very broad dicta addressing the topic generally coupled with a narrow holding addressing the issue in the case-has led many commentators and at least one circuit court of appeals to hold that Gant does not apply outside the vehicle context. ${ }^{107}$

Two phrases are key to understanding the difficulty of applying Gant outside the vehicle search context. First is Justice Stevens's pronouncement that a search incident to arrest is only reasonable when the "arrestee is unsecured." 108 In Gant, the arrestee was handcuffed and placed in a patrol car. ${ }^{109}$ But is the arrestee "secured" if she is only handcuffed? What if she is handcuffed and surrounded by officers? The second key phrase, which plays off of the first, is that such a search is reasonable only when the arrestee has "access" to the area being searched. ${ }^{110}$ Not only must courts determine if a person in handcuffs

\footnotetext{
99. New York v. Belton, 453 U.S. 454, 455 (1981).

100. Gant, 556 U.S. at 344.

101. Id.

102. Id.

103. Id

104. Id.

105. Id. at 343 .

106. Id

107. See infra Part III.

108. Gant, 556 U.S. at 343.

109. Id. at 344 .

110. Id.
} 
surrounded by police is actually secure, but they must also decide whether the person could access the container or the area being searched.

Justice Scalia concurred that Belton's bright-line rule was inconsistent with Chimel and the Court's historical justifications for vehicle searches incident to arrest. ${ }^{111}$ But, he wrote separately because he felt the Court's new rule - that "officers making a roadside stop may search the vehicle so long as the "arrestee is within reaching distance of the passenger compartment at the time of the search",112 — is not ideal for two practical reasons. First, this case-by-case rule fails to sufficiently guide officers in the field. ${ }^{113}$ Second, and more interestingly, such a rule, Justice Scalia felt, is ripe for manipulation; it invites "officers to leave the scene unsecured (at least where dangerous suspects are not involved) in order to conduct a vehicle search."114 After all, the best way to preserve officer safety is simply to arrest the person and put them in a patrol car. ${ }^{115}$ There is no reason, Justice Scalia argued, to go through this charade, and the police should just arrest the person if they have probable cause. ${ }^{116}$ Belton should be recognized for what it was: "a return to the broader sort of [evidence-gathering] search incident to arrest that we allowed before Chimel."117 Thus, he would simply abandon the BeltonThornton line of cases that focus on the officer-safety prong and focus on the evidence-gathering prong of Chimel:

[A] vehicle search incident to arrest is ipso facto "reasonable" only when the object of the search is evidence of the crime for which the arrest was made, or of another crime that the officer has probable cause to believe occurred. Because respondent was arrested for driving without a license (a crime for which no evidence could be expected to be found in the vehicle), I would hold in the present case that the search was unlawful.

Importantly, Justice Scalia argued that the Court was addressing only the search incident to arrest exception. ${ }^{119}$ Officers can always search a person in a car under Michigan $v$. Long and the car search exception to

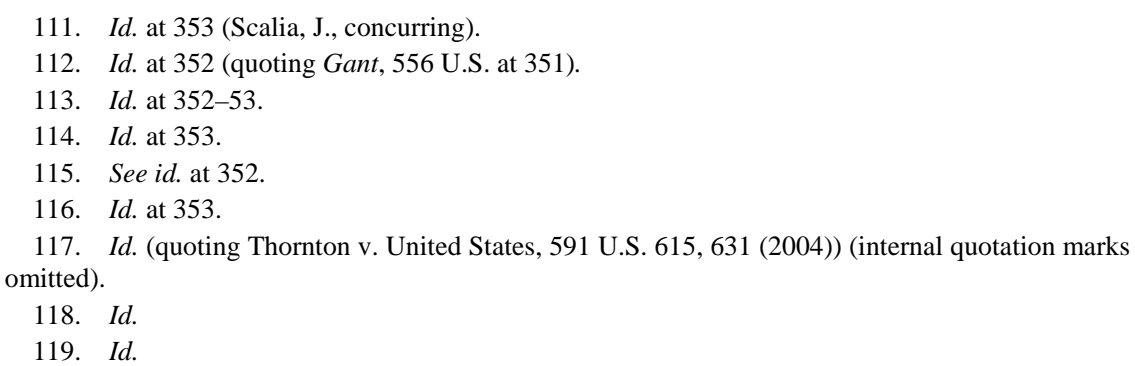


the warrant requirement when "they reasonably believe 'the suspect is dangerous and ... may gain immediate control of weapons.",120 "In the no-arrest case, the possibility of access to weapons in the vehicle always exists, since the driver or passenger will be allowed to return to the vehicle when the interrogation is completed."121 Thus, getting rid of the police-safety justification is reasonable.

Chief Justice Roberts and Justices Alito, Kennedy, and Breyer, dissented. Justice Breyer filed a dissenting opinion and joined Justice Alito's dissent as well. All dissenting Justices agreed that the bright-line rule laid out in Belton and followed for decades by federal and state courts should not be abandoned based on stare decisis. ${ }^{122}$ Additionally, the Court's decision to abandon Belton and Thornton's bright-line rule ignores the fact that police officers have been trained for decades on the rule and that the rule has proved workable in the field. ${ }^{123}$ While Justice Breyer would retain Belton's rule primarily because of stare decisis, ${ }^{124}$ Justice Alito argued that the Chimel Court likely did not intend for the area from which the arrestee may gain a weapon or destroy evidence to be measured from the area that the arrestee may access at the time of the search, as the majority held. ${ }^{125}$ Rather, the area should be measured at the time of the arrest, because by measuring it at the time of the search, the rule incentivizes officers to not secure the scene. ${ }^{126}$ Measuring the area to be searched at the time of arrest would allow an officer to secure the scene and search the car, which is essentially Belton's rule.

\section{FEDERAL COURT DECISIONS}

Two circuit courts and one district court have ruled on whether Gant extends outside the vehicle context. The United States Court of Appeals for the Third Circuit held that Gant extends outside the vehicle context to all searches incident to an arrest. ${ }^{127}$ The Third Circuit's test allows a search if (1) the arrestee has "access" to the container and (2) one of the two Chimel factors-officer safety and evidence preservation-exists. ${ }^{128}$

\footnotetext{
120. Id. at 352 (alteration in original) (quoting Michigan v. Long, 463 U.S. 1032, 1049 (1983)).

121. Id.

122. Id. at 354-55 (Breyer, J., dissenting) (agreeing with dissent that stare decisis principles apply but disagreeing that Belton was a reasonable extension of Chimel).

123. See id. at 358-60 (Alito, J., dissenting).

124. Id. at 354 (Breyer, J., dissenting).

125. Id. at 361-62 (Alito, J., dissenting).

126. Id. at 362 .

127. United States v. Shakir, 616 F.3d 315, 318 (3d Cir. 2010).

128. Id. at 321 .
} 
This Comment calls this the "access factor test." Conversely, the United States Court of Appeals for the Eighth Circuit declined to apply Gant outside the vehicle context. ${ }^{129}$ Lastly, although the Tenth Circuit has not addressed the issue, Chief Judge Claire Eagan of the United States District Court for the Northern District of Oklahoma held that Gant applies to all searches incident to arrest. ${ }^{130}$ She also adopted the Third Circuit's access factor test. This following section outlines these cases.

\section{A. The Third Circuit's Approach}

The Third Circuit addressed whether Gant applies outside the vehicle context in United States $v$. Shakir. ${ }^{131}$ Shakir was arrested in the lobby of a casino pursuant to an arrest warrant for an armed bank robbery that occurred a month earlier. ${ }^{132}$ As the police placed Shakir under arrest, he dropped his bag on the ground. ${ }^{133}$ The officers then patted him down, waited for backup, and put him in handcuffs. ${ }^{134}$ Instead of placing him in a squad car, the officers held Shakir a short distance away while another officer searched his bag. ${ }^{135}$ In the bag, officers found cash from the robbery. ${ }^{136}$ Shakir later argued that evidence discovered in his container pursuant to a lawful arrest should be suppressed based on the Supreme Court's decision in Gant. ${ }^{137}$ Shakir argued, consistent with Gant, that the search was unjustified because he was already secured by handcuffs without the ability to destroy evidence or gain a weapon from the bag. ${ }^{138}$ The district court denied his suppression motion, and the money recovered helped win his conviction. ${ }^{139}$

The Third Circuit affirmed the district court's denial of the motion to suppress. ${ }^{140}$ First, the court reasoned that although Gant's holding was narrow, it was not so narrow, especially read in tandem with its broad dicta, that it applies only to searches incident to arrests when the area

\footnotetext{
129. See infra Part III.B.

130. See infra Part III.C.

131. 616 F.3d at 318.

132. Id. at 316

133. Id.

134. Id. at 316-17.

135. Id.

136. Id. at 317.

137. Id.

138. Id.

139. Id.

140. Id. at 321.
} 
being searched is a vehicle rather than a bag. ${ }^{141}$ The court explained that Gant applies to "any situation where the item searched is removed from the suspect's control between the time of the arrest and the time of the search." 142 The Shakir court noted that the reason Gant applies broadly is because Gant refocused the exception on the policy justifications outlined in Chimel; or, in other words, the focus had returned to whether the suspect had the ability to access weapons or destroy evidence at the time of the search. ${ }^{143}$ The Third Circuit stated:

[T] hat a search is permissible incident to a suspect's arrest when, under all the circumstances, there remains a reasonable possibility that the arrestee could access a weapon or destructible evidence in the container or area being searched. Although this standard requires something more than the mere theoretical possibility that a suspect might access a weapon or evidence, it remains a lenient standard. ${ }^{14}$

After concluding that Gant applies outside the vehicle context, the court created a test to do just that. The court held that a search is valid if, under all the circumstances, the suspect "retained sufficient potential access to his bag” in order to access a weapon or destroy evidence. ${ }^{145}$ Under this test, the search of Shakir's bag was reasonable. ${ }^{146}$ Shakir, despite being secured, retained potential access to his bag. ${ }^{147}$ Next, it was likely he could have gained access to a weapon. ${ }^{148}$ Therefore, the search was valid under Chimel's officer-safety prong. ${ }^{149}$ He was near the bag, there was evidence that could suggest he had accomplices in the growing crowd, and was restrained only by two unarmed security guards. ${ }^{150}$

Shakir was handcuffed, but the court still felt he was not "secure" under Gant because he retained potential "access" to the areas searched. Most lay people would assume that once a suspect is handcuffed, he is "secure." So, why not forbid all container searches once the suspect is handcuffed? The court observed that under a literal interpretation of Gant's unsecured requirement, “once a suspect is 'secured,' no searches

\footnotetext{
141. Id. at 318.

142. Id.

143. Id.

144. Id. at 321 .

145. Id. at 319, 321.

146. Id. at 321 .

147. Id.

148. Id.

149. Id.

150. Id.
} 
would be permitted incident to his arrest, regardless of whether the searched items are within his reaching distance." downplayed Gant's focus on whether the suspect is secured or unsecured at the time of the search. ${ }^{152}$ The court felt this approach, especially for container searches, was too lenient for two reasons. First, such an "aggressive" reading was inconsistent with Gant because Gant really focused on the suspect's ability to access the vehicle, not simply on her secured status or where she was placed in relation to the car. ${ }^{153}$ If the suspect was secured, or placed in the police car, then she could not access the car. ${ }^{154}$ Indeed, whether the suspect is secured or placed in a car are only two of the many ways that a suspect could be seen not to have access to the area police wish to search. ${ }^{155}$ Therefore, the court focused on Gant's second key phrase “access," and concluded that Gant really "stand[s] for the proposition that police cannot search a location or item when there is no reasonable possibility that the suspect might access it." ${ }^{\text {} 156}$ Second, placing a suspect in handcuffs is not a final act of submission; indeed, the court noted, "handcuffs are not fail-safe." 157

\section{B. The Eighth Circuit's Approach}

The Eighth Circuit has issued two opinions, both authored by Judge Raymond Gruender, addressing whether Gant extends to searches outside the vehicle context. In contrast to the Third Circuit, the Eighth Circuit reads Gant narrowly and declines to apply it outside the vehicle context. ${ }^{158}$

The first case handled by the Eighth Circuit and Judge Gruender addressing whether Gant's restrictions apply outside the vehicle context was United States $v$. Brewer. ${ }^{159}$ Edward Brewer was arrested in his car for distributing crack cocaine after a prearranged buy with an undercover

\footnotetext{
151. Id. at 320 .

152. See id. (stating that Gant "could be read to prohibit the search of the bag unless at the time of the search Shakir was both (1) unsecured and (2) within reaching distance of the bag”).

153. Id.

154. Id

155. Id.

156. Id.

157. Id.

158. See United States v. Brewer, 624 F.3d 900, 906 (8th Cir. 2010), cert. denied, 131 S. Ct. 1805 (2011) ("Because the [evidence] was seized from Brewer's pants pocket, the holding in Gant concerning when the police may search the passenger compartment of a vehicle incident to arrest does not apply.").
}

159. Id. 
agent. $^{160}$ Having learned earlier that Brewer's driver's license was suspended, police officers trailed Brewer as he left the buy, pulled him over, and arrested him in the vehicle based on the license violation. ${ }^{161}$ After arresting him for the license violation, the police recovered $\$ 800$ in recorded bills that the undercover agent used in the buy from a pocket in Brewer's pants. ${ }^{162}$

Brewer moved to suppress the money, arguing "that the search of his van was not a valid search incident to arrest because, after he exited the van and was arrested, the arresting officers could not have reasonably believed that he could access the interior of the van." ${ }^{163}$ Although the Eighth Circuit found this argument "nettlesome" for the government and that searches without warrants are presumptively unreasonable, it upheld the search as a valid search incident to arrest. ${ }^{164}$

Exactly where the money was recovered-whether it was found in Brewer's pants or from a search of the van-mattered to the Eighth Circuit. ${ }^{165}$ If the money had been recovered after an automobile search, then Gant would have applied ${ }^{166}$ and the state would have had to show that Brewer had access to the vehicle at the time of the search. ${ }^{167}$ But, the weight of the evidence showed that the money was recovered after searching Brewer's person, not after a search of his car. ${ }^{168}$ Gant, the court held, simply did not apply to a search of a person. ${ }^{169}$

The second case the Eighth Circuit and Judge Gruender handled, United States $v$. Perdoma, ${ }^{170}$ discussed at much greater length whether Gant extends outside the vehicle context. In Perdoma, Jesus Perdoma moved to suppress evidence gathered from a search of his bag incident to a lawful arrest that occurred after he was handcuffed and surrounded by police officers. ${ }^{171}$ A plain-clothes police officer followed Perdoma as he

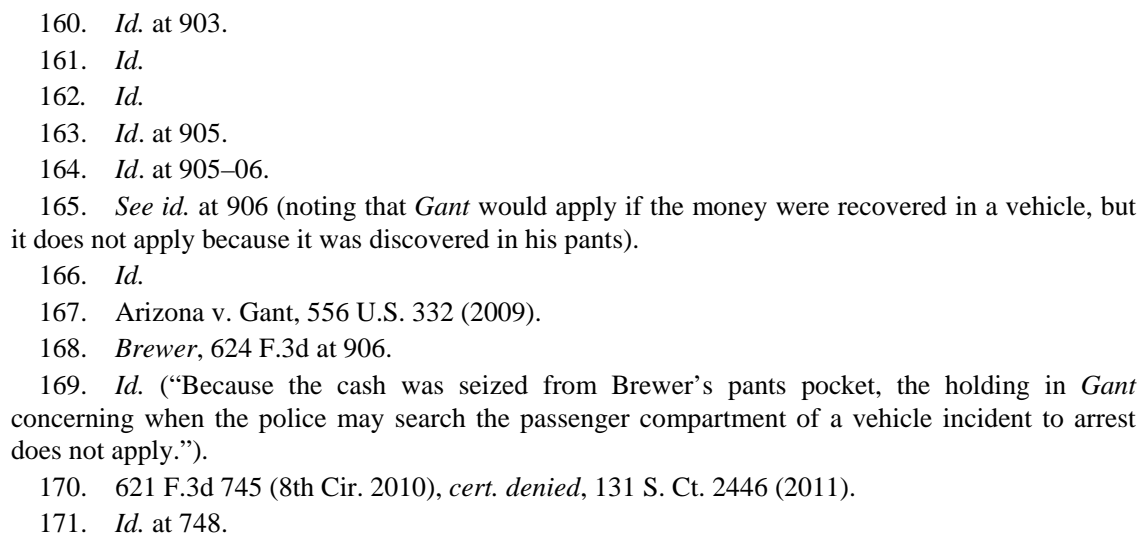


entered a Greyhound bus terminal. ${ }^{172}$ The officer overheard Perdoma buying a one-way ticket and noticed he was nervous and shaking the whole time. ${ }^{173}$ The officer approached Perdoma, identified himself as a police officer, and asked if he could speak to Perdoma. ${ }^{174}$ Perdoma consented to the casual conversation, but when the officer asked to see his wallet, Perdoma took off running. ${ }^{175}$ Officers quickly caught Perdoma, wrestled him to the ground, arrested him, handcuffed him, and moved him from the bus terminal's lobby to the terminal's rear area. ${ }^{176}$ The Eighth Circuit panel was unclear on key facts surrounding the discovery and search of Perdoma's bag. Judge Gruender's majority opinion notes that one officer searched Perdoma's person and found drugs while a second officer simultaneously searched Perdoma's bag in close proximity to where Perdoma was restrained in the terminal's rear and also found drugs. ${ }^{177}$ Judge Bye's dissent concluded that officers secured the bag in the terminal's lobby after Perdoma was under arrest and then carried the zipped bag from the lobby to the rear of the terminal. ${ }^{178}$ Judge Bye noted that the record indicated that the search of the bag did not occur until "after Perdoma had been apprehended, placed in handcuffs, and removed from the public terminal."179 The district court refused to extend Gant to this container search, and upheld it only because "it was reasonable for the officer to believe the defendant's bag would contain evidence of a drug crime."180

The majority of the Eighth Circuit panel held that the search was proper. $^{181}$ Judges Gruender and Gibson noted that although Gant may extend to searches incident to arrests outside the vehicle context, they would not rule on whether Gant's restrictions extend to this context because Perdoma did not properly raise the issue. ${ }^{182}$ But, shortly after

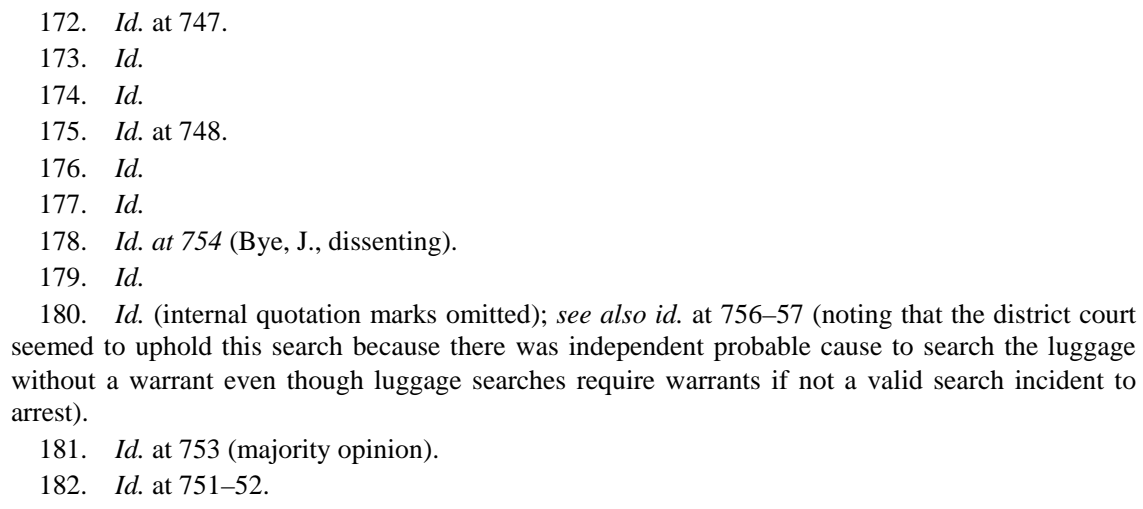


that pronouncement, the majority signaled its belief that Gant really is all about car searches: ${ }^{183}$

The dissent would hold that an arrestee who is restrained in some fashion by law enforcement necessarily is secured (as contemplated by Gant) such that a warrantless search incident to arrest of luggage in the arrestee's immediate area can never be justified. Gant does not support this logic. ... The Court [in Gant] focuses exclusively on how the rule will affect vehicle searches....

The potential pitfalls of the dissent's approach are aptly illustrated by a comparison of Gant to the instant case. The defendant in Gant parked at the end of a private driveway and was arrested, handcuffed, and locked in the back of a patrol car before his vehicle was searched. "Under those circumstances, Gant clearly was not within reaching distance of his car at the time of the search.” By contrast, here the record suggests that Perdoma was held in close proximity to his bag while it was searched. Given our repeated recognition in the nonvehicle search-incident-to-arrest context that it may be possible for an arrestee restrained in a room to reach items in that room, and without any argument as to why the Supreme Court's reasoning with respect to reaching into a vehicle in Gant should control in Perdoma's circumstances, we cannot say that the simple fact of Perdoma's arrest and restraint left Perdoma "clearly
his $[\mathrm{bag}]$ at the time of the search." ${ }^{8} 4$

The majority then noted that courts have repeatedly recognized that even handcuffed arrestees can access items in the room around them. ${ }^{185}$ The majority held that because Perdoma was near the bag when it was searched, as opposed to the suspect in Gant who was in the rear of a separate car at the time of the search, Gant's restrictions did not apply. ${ }^{186}$ In other words, simply putting an arrestee in handcuffs does not defeat the police's ability to search the area around her and the bags she had when arrested. ${ }^{187}$

183. See id. at 752 (emphasizing the specific situation that led to the Gant holding).

184. Id. at 752-53 (citations omitted) (quoting Arizona v. Gant, 556 U.S. 332 (2009)); see also id. at 756 (Bye, J., dissenting) ("While on the surface the majority purports not to address the issue of Gant's applicability outside the vehicle-search context, in substance it goes to great lengths to limit Gant to vehicle searches.” (citations omitted)).

185. Id. at 753 (majority opinion).

186. Id.

187. Id. 
Judge Bye dissented, and argued that the Court's desire to retether the search incident to arrest exception to the Chimel factors means that the same test for Gant controls every search incident to arrest:

For one, all Gant does is return the analysis of the search incident to arrest exception to the familiar moorings of Chimel, a case that did not deal with a vehicle search. Two, it is clear that Gant contemplates that its Chimel-based rationale would apply to non-vehicle searches because the opinion goes through [the] trouble of stating that the other part of its rationale-that based on Thornton $v$. United States-applies only in "circumstances unique to the vehicle context." And three, we previously have had little trouble concluding that the Belton principles translate into non-vehicle contexts. There is no reason why having done so, we should now circumscribe invalidation of the same Belton principles to a vehicle context only. ${ }^{188}$

Gant held that a search is valid only "when the arrestee is unsecured and within reaching distance of the passenger compartment" of the vehicle. ${ }^{189}$ Applying Gant to Perdoma's facts, Judge Bye argued that the evidence found in Perdoma's bag merited suppression. ${ }^{190}$ Perdoma was handcuffed and secured by two police officers. ${ }^{191}$ The bag was not in close proximity to Perdoma who was being searched contemporaneously with the search of his bag. ${ }^{192}$ He therefore was both secure and unable to access his bag at the time it was searched. ${ }^{193}$ The possibility that Perdoma could reach his bag was too remote to be a valid concern. ${ }^{194}$ In short, to Judge Bye, Gant applies broadly, overriding bright-line rules and restricting previously justifiable searches that are "untethered to any interest in protecting officer safety or safeguarding evidence.”195

\section{The Northern District of Oklahoma's Approach}

In United States $v$. Cartwright, the Northern District of Oklahoma held that Gant applies outside the vehicle context and adopted the Third Circuit's access factor test. ${ }^{196}$ Cartwright was a prison escapee whom

\footnotetext{
188. Id. at 756 (Bye, J., dissenting) (citations omitted) (quoting Gant, 556 U.S. at 343).

189. Id. (quoting Gant, 556 U.S. at 343).

190. Id. at 757.

191. Id.

192. Id.

193. Id.

194. See id. (outlining how difficult it would have been for Perdoma to break through the officers' custody and get to his bag).

195. Id.

196. No. 10-CR-104-CVE, 2010 WL 3931102, at *10 (N.D. Okla. Oct. 5, 2010), aff'd, 678 F.3d
} 
police tracked to an Oklahoma motel. ${ }^{197}$ Police staked out the hotel and approached him when he left his room. ${ }^{198}$ During his arrest, Cartwright dropped the duffel bag he had been carrying. ${ }^{199}$ When asked if he had any weapons on his person, he admitted there was ammunition in the duffel bag. ${ }^{200}$ Another agent walked Cartwright's bag away from him, searched it, and found the ammunition. ${ }^{201}$ Based on that ammunition, Cartwright was charged as a felon in possession of ammunition. ${ }^{202}$

Judge Eagan, like the Third Circuit, held Gant applies outside the vehicle context, and indicated that the access factor test is the best way to implement Gant. ${ }^{203}$ Judge Eagan outlined several important factors to consider when applying the access factor test, including whether and how the arrestee was restrained, where the arrest and search occurred, and whether the suspect was thought to be acting alone. ${ }^{204}$ Judge Eagan upheld the validity of the search of the bag incident to arrest because Cartwright still had an objectively reasonable ability to access his bag. ${ }^{205}$ Lastly, the mere fact that the suspect is handcuffed and seemingly secured by the police "does not eliminate the risk that he will gain access to a weapon."206

\section{ANALYSIS AND PROPOSED APPROACH}

This Comment's analysis section argues two main points. First, Gant's restrictions to the search incident to arrest exception-that a search can occur when the arrestee is unsecured and within reaching distance of the area-should not be limited to the vehicle context. Second, the Third Circuit's access factor test is the best way to rectify Chimel v. California's policy concerns and account for Gant's modifications. Although factor tests do inject a modicum of uncertainty into police-arrestee encounters generally, such a test is the best way to

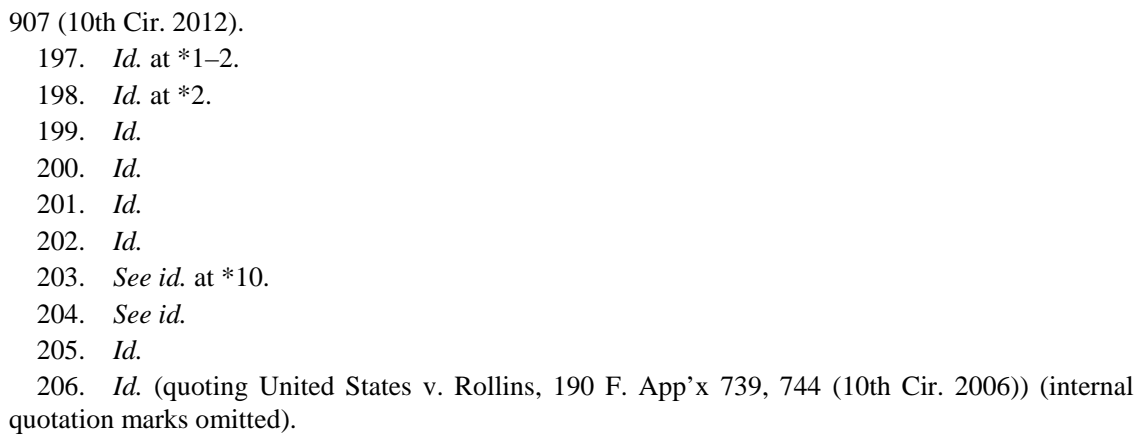


protect the Fourth Amendment's warrant requirement and ensure that exceptions are narrowly construed.

\section{A. Gant Should Be Extended to All Searches Incident to Arrest}

Although Gant's narrow holding addressed only vehicle searches, Gant should apply to all searches incident to arrest for four reasons. First, access is the key factor in determining whether a search is valid because an arrestee must have access to the area to gain a weapon or destroy evidence. Next, Gant resurrected and retethered the search incident to arrest exception to the original policy goals stated in Chimel, which itself did not concern car searches. Third, by explicitly overturning Belton's bright-line rule, the Court indicated that it is comfortable moving away from bright-line rules if those rules are divorced from Chimel's policy goals. Finally, broad application of Gant's restrictions is consistent with the need to narrowly limit any exception to the Fourth Amendment's warrant requirement. Just as the swordsman in William Goldman's The Princess Bride was forced to restart his journey after straying from his goal, so too has the Court gone "back to the beginning," 207 deciding to restart its search incident to arrest jurisprudence while keeping the original justifications in mind.

First, although Gant's narrow holding addressed only vehicle searches, Gant's reasoning extends outside the vehicle context. Gant and the Third Circuit's approach focus on whether the arrestee has access to the area to be searched. ${ }^{208}$ In Gant, the Court noted that no one argued that "Chimel authorizes a vehicle search incident to arrest when there is no realistic possibility that an arrestee could access his vehicle."209 When the arrestee cannot access the searched area at the time of the search, the Court noted, then there is no possibility that the Chimel prongs are satisfied; if there is no access, then the arrestee cannot get a weapon to harm the officer or destroy evidence. ${ }^{210}$ An access limitation "ensures that the scope of a search incident to arrest is commensurate with its purposes of protecting arresting officers and safeguarding any evidence of the offense of arrest that an arrestee might conceal or destroy."211

\footnotetext{
207. William GOLdMAN, THE PRINCESS BRIDE (1973).

208. See infra Part IV.B.

209. Arizona v. Gant, 556 U.S. 332, 340 (2009).

210. Id. at 339 .

211. Id.
} 
This reasoning extends outside the vehicle context. For example, imagine that a police officer encounters a suspect whom she knows has a warrant out for armed robbery. If the suspect drops her bag and is subsequently arrested and placed in the back of a police cruiser, can the arresting officer walk back to the bag and search it? Before Gant-and in courts that refuse to extend Gant outside the vehicle context-this search would be allowed. But under Gant, the search would only be allowed if the court believes the arrestee retained the possibility of accessing the bag. Only then could the arrestee gain a weapon or destroy evidence. Although this interpretation may not alter when an officer can conduct a search in a vast majority of cases outside those involving an automobile, the alteration is necessary to carry out Chimel's policy goals.

Second, Gant extends to all searches because the Court replanted the entire doctrine in Chimel, a case that did not concern automobile searches. The fact that the Court reiterated Chimel's policy concerns in a vehicle context does not lead to the conclusion that the restrictions apply only to vehicle searches. Indeed, the Court construed Chimel to stand for the principle that any

area from within which [the arrestee] might gain possession of a weapon or destructible evidence ... continues to define the boundaries of the exception, ensur[ing] that the scope of a search incident to arrest is commensurate with its purposes of protecting arresting officers and safeguarding any evidence of the offense of arrest that an arrestee might conceal or destroy. ${ }^{21}$

Chimel did not involve an automobile search, but the proper scope of a search incident to an arrest is the area surrounding the arrestee in his home. ${ }^{213}$ Thus, because Chimel did not deal with automobile searches, and Gant's holding overturned Belton and retethered automobile searches to a nonautomobile case, it does not follow that Gant fails to apply outside the vehicle context. This is essentially the transitive theory: Belton concerns Chimel's "application to the automobile context."214 Gant reversed Belton as inconsistent with Chimel because when the person has no access to the area, she is per se unable to gain a weapon or destroy evidence. Thus, any search in which the arrestee does not have access to the area being searched is inconsistent with Chimel as modified by Gant.

\footnotetext{
212. Id.

213. See supra Part II.A.

214. Gant, 556 U.S. at 339.
} 
Another lens through which to view this progression is simpler: Gant's broad dicta govern all searches incident to arrest. The Court did not issue a broad holding because the only issue before it was whether Belton was inconsistent with Chimel. ${ }^{215}$ Nevertheless, a search is only proper if the arrestee is unsecured and within reaching distance-or has access to-the area of the search at the time of the search. ${ }^{216}$ The emphasis on Chimel's twin purposes should be read as an attempt by the Court to reassert the original purpose and meaning of the search incident to arrest exception.

Third, although officers in the field and courts prefer bright-line rules, Gant shows that this Court is comfortable straying from such rules if they are inconsistent with the Fourth Amendment and Chimel. Important, again, is the progression from Belton to Gant. Belton was the Court's attempt to "alleviate the case-by-case analysis that was taking place" at the time. ${ }^{217}$ Thus, because Gant repudiated Belton, it also signaled the Court's willingness to return, albeit gingerly, to a case-bycase approach.

Lastly, although there are countless exceptions, one must remember that the Fourth Amendment prohibits searches without a warrant. And the search incident to arrest doctrine is only an exception to a constitutional guarantee. ${ }^{218}$ This exception should be read narrowly and limited to those situations in which society does not require a neutral and detached magistrate to stand between the citizen and "the officer engaged in the .. . competitive enterprise of ferreting out crime." 119 Indeed, "[t]he point of the Fourth Amendment, which often is not grasped by zealous officers, is not that it denies law enforcement the support of the usual inferences which reasonable men draw from evidence."220 One should err on the side of respecting a constitutional guarantee. The most effective way to ground the search incident to arrest exception in the Chimel factors is to require police officers to determine case by case whether the person has access to the area being searched and whether the need to protect officer safety and preserve evidence is present. Indeed, the Court noted that "[c]onstruing Belton broadly to allow vehicle searches incident to any arrest would serve no purpose except to provide

\footnotetext{
215. See id. at 339-41.

216. See id. at 339.

217. Jeffrey R. Beck, Arizona v. Gant: Heightening a Person's Expectation of Privacy in a Motor Vehicle Following Searches Incident to Arrest, 55 S.D. L. REV. 299, 301 (2010).

218. See Gant, 556 U.S. at 338.

219. Johnson v. United States, 333 U.S. 10, 13-14 (1948).

220. Id.
} 
a police entitlement, and it is anathema to the Fourth Amendment to permit a warrantless search on that basis."221

The argument that Gant is limited to the vehicle context certainly has merit. The Eighth Circuit held that because the Court spoke of limiting the search in the vehicle context, the limitations likely did not extend further than the vehicle context. ${ }^{222}$ But, before discussing the exception in the vehicle context specifically, the Court first reiterated that Chimel's policy objectives lord over the exception generally. ${ }^{223}$ Because Gant conclusively stated that Chimel justifies and defines the exception, all searches now should be justified by a case-by-case determination that the search was needed either for officer safety or evidence gathering, which only occurs when the person has access to the area.

The battle between expanding police officers' search capability and expanding criminal defendants' right to be free from unreasonable searches is a zero-sum game; providing criminal defendants increased protections from searches chips away at police officers' ability to search. It is acceptable that some searches previously allowable are now unjustified, however, because the overriding purpose of the Fourth Amendment is to do just that: limit warrantless searches to only the times when they are needed most. Stating simply that police officers lose abilities to search is not a sufficient concern for continuing broad searches when the arrestee cannot access weapons or evidence in the area being searched.

\section{B. The Third Circuit's Access Factor Test Should Govern}

After concluding that Gant applies outside the vehicle context because the Chimel policy concerns require that the arrestee have the ability to access a weapon or destroy evidence from the area to be searched, one must fashion a test that accounts for this conclusion while also making the test as simple as possible for officers to apply in the field. Courts should adopt the Third Circuit's test that focuses on whether the arrestee has access to the area of the search at the time of the search. First, it comports with Gant's reestablishment of the Chimel justifications as the only proper justifications governing when a search incident to an arrest can occur as well as the scope of that search. Access

\footnotetext{
221. Gant, 556 U.S. at 347.

222. See supra Part III.B.

223. See Gant, U.S. 556 at 340-43 (noting that Chimel policy objectives govern the search incident to arrest doctrine before speaking about circumstances unique to the vehicle context).
} 
justifies the search because without access to the search area there is no way to satisfy either Chimel justification. If there is no access, the arrestee cannot get a weapon or destroy evidence. Therefore, an access limitation "ensures that the scope of a search incident to arrest is commensurate with its purposes of protecting arresting officers and safeguarding any evidence of the offense of arrest that an arrestee might conceal or destroy.",224

The Third Circuit in United States v. Shakir felt the applicable question courts must ask when evaluating a post-Gant container search incident to arrest is whether, under all the circumstances, the arrestee has retained "sufficient potential access to his bag" to access a weapon or destroy evidence. ${ }^{225}$ Gant focused on whether the suspect is secured and whether the suspect has access to the area. ${ }^{226}$ Shakir focused on whether the suspect has access to the area to be searched rather than simply holding the search invalid once the person is technically secured. ${ }^{227}$ But a test that considers whether the area being searched is one that the arrestee could access - the second prong of the Gant test-suits Gant's desire to reign in the scope of the search incident to arrest exception.

The test should focus on three main factors: (1) whether and how the arrestee is restrained, (2) where the arrest and search occur, and (3) whether the suspect is thought to be acting alone. Applying this test, the police's ability to search does not simply end once the suspect is handcuffed. ${ }^{228}$ All courts have held that handcuffs are not a surefire way to prevent someone from accessing weapons or destroying evidence; therefore, officers are often able to search a container or an area even after they have put the suspect in handcuffs and are waiting to place her in a car. ${ }^{229}$ But, once she is placed in the car, the need for the immediate, warrantless search ends, and the Fourth Amendment requires a warrant.

This test comports with Gant's reestablishment of the Chimel justifications by requiring that the arrestee have actual access to the area to be searched. Gant did two main things: (1) resurrected the Chimel policy justifications and (2) modified and strengthened those justifications by noting that the search is per se unreasonable when the person has no access to or is adequately secured from the area to be

224. Id. at 339 (citing Chimel v. California, 395 U.S. 752 (1969)).

225. 616 F.3d 315, 318, 320 (3d Cir. 2010); see also supra Part III.A.

226. Gant, 556 U.S. at 340.

227. Shakir, 616 F.3d at 318, 320; see also supra Part III.A.

228. See supra Part III.B.

229. See, e.g., Shakir, 616 F.3d at 317, 320 (“[H]andcuffs are not fail-safe.”). 
searched. ${ }^{230}$ A showing of access must not be limited to vehicle searches, but should extend to all searches incident to arrest. Access, as the access factor test recognizes, is the key element to Gant and Chimel.

A case-by-case analysis is necessary to ensure that Fourth Amendment protections are not swallowed by a broad search incident to arrest exception. In Gant, the Court signaled its desire to abandon Belton and return to Chimel. ${ }^{231}$ Because Belton itself was an attempt to "alleviate the case-by-case analysis that was taking place" at the time, ${ }^{232}$ it follows that the Court is comfortable with, or even wanted, a return to a case-by-case analysis. The Third Circuit's access factor test is the best method for undertaking this case-by-case analysis without making it overly complicated. This approach best addresses the Supreme Court's desire to reconnect the search incident to arrest with the need to protect officer safety and evidence gathering while balancing that desire against the Fourth Amendment's guarantee that people be free from warrantless searches.

This approach provides police a wide berth to search, but curtails borderline searches that are "anathema to the Fourth amendment."233 The Eighth Circuit case United States v. Perdoma is one example of the type of search, routinely upheld before Gant's extension outside the vehicle context, that should be considered anathema to the Fourth Amendment after Gant. ${ }^{234}$ Although the access factor test is relatively malleable - which should give government officials reason to like it-it cannot be contorted to uphold the search in Perdoma where the suspect was secured by two officers, the bag was carried by the police from where Perdoma dropped it to the area near where Perdoma was being held, and there was no indication of nearby accomplices. ${ }^{235}$

Perdoma can be analyzed using the three factors outlined above. ${ }^{236}$ First, the suspect was secured-he was in handcuffs and surrounded by a few police officers with handguns at the time of the search. ${ }^{237}$ This strongly suggests that he could not have accessed the bag and that the Chimel justifications no longer existed there; after all, if he cannot access the bag, how can he grab a weapon or destroy evidence? Next, the

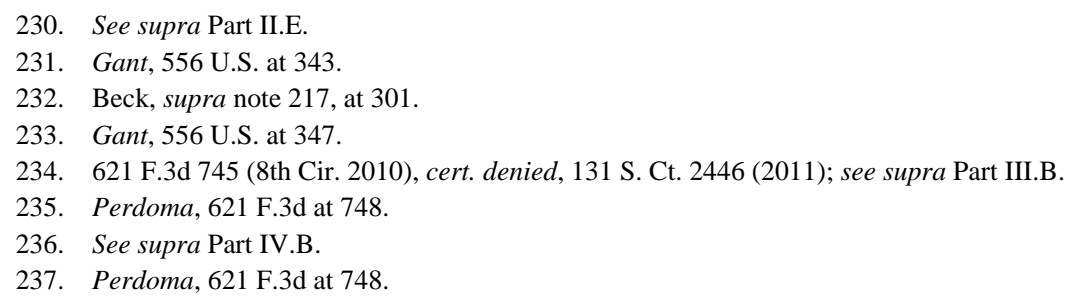


officer found the bag at a distance from where Perdoma was secured, carried the bag back to the area where Perdoma was held, and only then searched the bag while Perdoma was secured by two officers. Again, this cautions that he could not have accessed the bag. Lastly, there is no indication in the case that the suspect was thought to have accomplices in the area because he was dropped off alone, he had not spoken with anyone, and the police had no information that the suspect was meeting anyone. ${ }^{238}$ Although the police certainly wanted to avoid the hassle of obtaining a warrant, this search was not justified.

The first factor of the access factor test-whether the suspect is secured-is the most critical and merits more discussion. Certainly, as the Eighth Circuit stated in Perdoma, a handcuffed suspect could possibly escape the grip of her captors and access "items in that room.”239 But, certainly at some point a suspect is sufficiently secured, yet still outside a patrol car, that she could not reasonably access the area to be searched. The argument that a suspect who is handcuffed, surrounded by a number of armed officers, and held at a distance from the area to be searched is still unsecured and able to access the area is at some point unsupportable. Indeed, such a holding is a Belton-like legal fiction that the Court repudiated in Gant. ${ }^{240}$ In Belton, the Court concluded the entire passenger compartment of the car was per se within an arrestee's reaching distance. ${ }^{241}$ Similarly, concluding that a restrained and secured suspect could hypothetically escape the grasp of a team of officers to access a certain area to uphold the search commits the same error that Gant corrected. Lower courts should apply Gant's theory, and its broad dicta, to hold unreasonable these previously justifiable searches.

Thus, the Third Circuit's test is preferable. It reestablishes the Chimel prongs while strengthening the analysis by focusing on whether the arrestee has access to the area, which dictates whether he could gain a weapon or evidence. Even still, it is relatively simple to apply, especially for a factor test. Searches anathema to the Fourth Amendment must not be tolerated, and applying the access factor test to borderline searches outside the vehicle context is a great start to reestablishing the warrant requirement.

\section{Problems with the Approach}

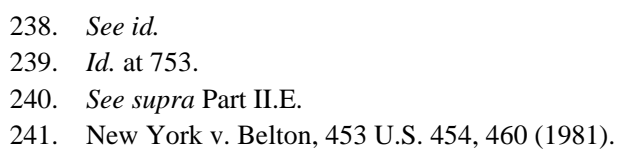


Without bright-line rules, courts are left to determine whether a police officer's search is justified as necessary for officer protection or evidence gathering on a case-by-case basis. The most obvious problem is that this test is not a hard-and-fast rule; a court will now require officers operating in confusing environments to determine whether the arrestee has access to the container or area of the room before they can search. Certainly, the rule established by the Third Circuit and advocated for in this Comment cuts against what Justice Rehnquist wanted to avoid by establishing bright-line rules:

A custodial arrest is fluid and "[t]he danger to the police officer flows from the fact of the arrest, and its attendant proximity, stress, and uncertainty,".... The stress is no less merely because the arrestee exited his car before the officer initiated contact, nor is an arrestee less likely to attempt to lunge for a weapon or to destroy evidence if he is outside of, but still in control of, the vehicle. In either case, the officer faces a highly volatile situation. It would make little sense to apply two different rules to what is, at bottom, the same situation.

In some circumstances it may be safer and more effective for officers to conceal their presence from a suspect until he has left his vehicle. Certainly that is a judgment officers should be free to make. .. . The Fourth Amendment does not require such a gamble. ${ }^{242}$

Unfortunately, there is no way to marry true adherence to the Chimel justifications and bright-line rules. A determination that one or both of the Chimel justifications is met-as the Court required in Gant-can only be done after a police officer surveys the scene. But, this restriction comports with the fact that searches incident to a lawful arrest are exceptions to the general warrant requirement. Warrants require approval on a case-by-case basis and are not given out in bunches. Once there is no danger to police officers, the search incident to arrest justifications are largely moot, and the judicial process should take its rightful place governing the relationship between society and an arrestee.

The dissenting Justices in Gant felt that the majority's restrictions would have the perverse effect of decreasing officer safety because officers would risk keeping suspects unsecured so they can have free reign to search. ${ }^{243}$ First, this is only troublesome from an officer-safety perspective if one assumes that officers keep dangerous people unsecured out in the open to avoid the pain of getting a warrant to

242. Thornton v. United States, 541 U.S. 615, 621-22 (2004) (citation omitted) (quoting United States v. Robinson, 414 U.S. 218, 234 n.5 (1973)).

243. See supra Part II.E. 
conduct a search of an area that would otherwise be off-limits post-Gant. One hopes police officers would secure their own safety before digging through a backpack looking for evidence they likely could access in a short time either by getting a warrant or through another exception. A second answer is that while the officer-safety criticism may be valid, it is a red herring. The Fourth Amendment provides protections for the general public, not law enforcement, and its protections are not an annoyance but a central tenet of America's criminal justice system.

Gant's restrictions should apply to all searches incident to arrests, and such a search is improper if the arrestee does not have access to the area searched at the time of the search. Although such a rule could prove frustrating to zealous officers, erring on the side of more-vigorous protection of a constitutional protection is always preferable. Lastly, arresting officers may always search a person to protect themselves and "always have a less intrusive and more effective means of ensuring their safety-and a means that is virtually always employed: ordering the arrestee away from the vehicle, patting him down in the open, handcuffing him, and placing him in the squad car."244

Finally, as noted above, this test sets a higher bar than simply allowing an officer to search whenever there is reason to believe evidence of the crime may be found. But, this higher standard is justified because "searches conducted outside the judicial process, without prior approval by judge or magistrate, are per se unreasonable under the Fourth Amendment - subject only to a few specifically established and well-delineated exceptions." 245

\section{CONCLUSION}

The restrictions placed on vehicle searches in Gant should extend to all searches incident to an arrest. The Supreme Court had been in the business of creating bright-line rules governing the search incident to arrest exception for thirty years before Gant. But, any search that is incompatible with the underlying policy concerns the Court announced in Chimel and reestablished in Gant-the need to prevent the arrestee from gaining a weapon or destroying evidence-cannot be tolerated no matter how easy to apply the rule is. Gant should extend outside the vehicle context because Gant's reasoning easily applies to all searches incident to arrest; the only way an arrestee may get a weapon or destroy

244. Arizona v. Gant, 556 U.S. 332, 351-52 (2009) (Scalia, J., concurring).

245. Id. at 338 (quoting Katz v. United States, 389 U.S. 347, 357 (1967)). 
evidence is if she has access to the area to be searched at the time of the search. Thus, access is the key to creating a test that respects the Fourth Amendment's general prohibition against warrantless searches. In short, Gant changed everything. It destroyed Belton's bright-line rule governing vehicle searches and indicated a likely death for all other searches incident to arrest that are not justified by either officer safety or evidence preservation.

Courts around the country are now being asked to fashion new rules governing searches incident to arrest for container searches, room searches, and luggage searches. These new rules not only should conform to the Chimel justifications, but also should recognize that these decisions are made in tense, murky situations. The Third Circuit's access factor test as enhanced by the Northern District of Oklahoma is the preferable test. This test respects the Fourth Amendment, requires officers to justify searches by satisfying one of the two Chimel prongs, and, because it is limited in its number of factors, is relatively easy to apply in the field. The Fourth Amendment requires such a rule. 